九州大学学術情報リポジトリ

Kyushu University Institutional Repository

\title{
A Partnership Development Process Assessment Scale for Public Health Nurses in Japan
}

重松，由佳子

ht tps://doi. org/10.15017/1500547

出版情報 : 九州大学，2014，博士（看護学），課程博士 バージョン：

権利関係 : 全文ファイル公表済 
博士論文

A Partnership Development Process Assessment Scale for Public Health Nurses in Japan

日本における保健師の地域組織との

パートナーシップ構築プロセス評価尺度の開発

九州大学大学院医学系学府保健学専攻

博士後期課程

重松 由佳子

2015 


\section{Doctoral Dissertation}

\section{A Partnership Development Process Assessment Scale for Public Health Nurses in Japan}

Department of Health Sciences Graduate School of Medical Sciences Kyushu University

Yukako Shigematsu 


\begin{abstract}
Objective: The objective of this study was to develop and test a Partnership Development Process Assessment (PDPA) scale for content and construct validity and internal consistency reliability. This is needed to document and evaluate community health partnership development processes between public health nurses and community-based organizations in Japan.

Design: The study was conducted in three phases. Ten semi-structured interviews were conducted to generate items for a new scale. Thirty items were generated and reviewed by an expert panel for content validity and item refinement. A national postal survey of public health nurses was conducted to determine the scale’s internal structure, evaluate its reliability, and explore its construct and criterion validity.
\end{abstract}

Measurements: Validity and reliability testing of the PDPA scale using a content validity index and analysis of correlations with an existing scale were performed.

Results: Twenty-six items were selected and grouped into four factors: activities to share roles to manage community health issues, platform activities to support partnerships, activities to evaluate partnership practices, and activities to share information regarding community health issues. After factor analysis, 23 items were retained.

Conclusion: The PDPA scale is a valid and reliable instrument for public health nurses to assess partnership development activities.

Keywords: assessment scale, community-based, instrument validation, Organizations, partnership, public health nurse 


\section{Background}

Modern society and lifestyle have introduced new challenges to public health. Japan has

been facing significant demographic changes, with an increasingly aging population and a

decreasing childbirth rate, resulting in an accelerating demand for health and social care and

chronic condition management. Continuing health inequalities are intensified by financial

instability and income gaps due to an ongoing recession. There is growing interest and need for

health and wellbeing among individuals and communities.

Traditionally, Japanese public health services are funded and governed by local government. Public Health Nurses (PHNs) are frontline workers that provide health promotion activities in the community, and also play a vital role in administering local public health offices.

Their role also includes facilitating community activities and partnership scheme with community-based organizations. They are actively involved in establishing a trusting relationship with the community, gathering information, conducting analyses and assessment, and planning and administering solutions to public health problems (Yoshioka-Maeda, et al., 2006).

Communication and cooperation between public, private, non-profit organizations and community-based organizations are vital to meet population needs. Community health issues are 
complex and linked to diverse social, cultural, economic, environmental, and political factors.

Evidence suggests that an integrated approach and partnership between organizations from different backgrounds is beneficial for improving health outcomes, despite the variations in mission, focus, funding, expertise, and other characteristics of organizations. The World Health Organization [WHO] (2010) has advised that all sectors involved in health and wellbeing, as well as all levels of government (from local and regional to national and international), must take part in developing and maintaining successful partnerships with other organizations.

Partnership means to working together while recognizing expertise and establishing an agreement in shared roles and responsibilities for the achievement of mutual aims (Chrisman, Senturia, Tang, and Gheisar, 2002). Partnership in community health can have many positive effects, such as improving mutual understanding, developing learning opportunities, embedding responsibilities, ensuring accountabilities, reducing inequality in public health services, avoiding duplication of services, and enhancing convenience and efficiency (O’Mara-Eves et al., 2013).

Public health professionals are expected to play an important and active role in partnership development in the community and to have sufficient knowledge and skills (Public Health Agency of Canada, 2008). Indeed, their leadership skills should enable them to facilitate 
the active involvement of community organizations in public health initiatives (Courtney, Ballard, Fauver, Gariota, \& Holland, 1996). It is also important for public health professionals to collaborate with community-based organizations to develop strategies, acknowledge community activities, and define ways to improve public health outcomes (Kegler, Norton, \& Aronson, 2008). In Japan, PHNs are expected to play significant roles in community partnership development, serving as both service providers and administrators of local healthcare policy.

Evidence suggests that there are important processes and factors for achieving a successful partnership. Factors contributing to successful partnerships include satisfactory accountability, mutual commitment and trust, and evaluating activities (Dowling, Powell, \& Glendinning, 2004). An assessment scale can be useful for evaluating and highlighting areas for improvement. One such scale has already been developed in Australia; this scale, called the partnership analysis scale, includes seven factors that reflect aspects of a good partnership (VicHealth, 2011).

However, there are differences in community health partnership processes between Japan and Western countries, such as Australia. In Western countries, public health professionals create partnerships to further a central strategic process that is firmly ensconced in 
evidence-based practice and mutual aims and targets. On the other hand, partnerships in Japan are created by establishing close, trusting relationships between individuals or organizations from different backgrounds before the notion of an official partnership is even broached (Suzuki et al., 2008).

Little research exists on the assessment of the partnership development process in cases where prior trusting relationships between organizations and PHNs are essential, as in Japan. There are concerns that a lack of partnerships between the local authority and community-based organizations may reduce potential benefits of a strategic approach to meet community needs and policy making (Yamashita, 2013). Following a report from the Japanese Ministry of Health, Labor and Welfare (2012), A Direction for Comprehensive Implementation of National Health Promotion of which the promotion of partnerships between governmental and community-based organizations are a key component, there is an urgent need for the development of an assessment scale that caters to the unique aspects of the Japanese system.

Study Aims. The aim of the study was to develop and pilot test an instrument that PHNs in Japan could use to document and evaluate the partnership process. 


\section{Methods}

\section{Design and Sample}

The study employed three phases: qualitative interviews to develop content, determining content validity, and psychometric testing of the items using factor analysis and criterion validity (Funashima, 2009).

Development and content validity of the scale items. First, qualitative semi-structured

interviews were conducted individually with 10 public health nurses to identify items for the new instrument. Participants were recruited through advertisements in national newsletters and journals that specialized in public health and community-based activities. All participants had experience in interacting with community-based organizations that focused on community health issues and gave written informed consent.

Participants were given the following instructions. The opening question was asking them to describe their experience with a partnership development process with community-based organizations. They were then asked to: 1) describe the details of the partnership, That is, the purpose and nature of the partnership in which they have been involved, their roles, how they 
developed the partnership, and achievement and outcomes; 2) describe the details of interactions with community-based organizations, for example, preparatory process, direct and indirect interactions, and feedback; and 3) describe the things they have not done but they consider important in partnership activities. In order to generate broad responses, no one definition of partnership was provided to the participants.

Interviews were audiotaped. Qualitative coding was used to identify specific activities in partnership development and sustainability undertaken by public health nurses. Data processing involved inductive processes of creating potential items for the scale, wording and clarifying the items, subsequently generating categories and constructive analysis (Lincoln and Guba, 1985). Further processes to refine categories included comparing items applicable to each category, integrating categories and their properties, applying delimiting theory, and a thorough literature review and expert consultations. To ensure reliability, four interviewees were approached for an additional telephone interview to define and revise interpretations from their previous interviews. After coding, all ten participants were asked to comment on whether the analyzed data reflected the contents of the interview. After examining the interview transcripts, 27 potential items were generated to describe the activities and interactions involved in the process of establishing a 
partnership with community-based organizations. In the following process of a literature review and expert consultation, three items were added to 27 potential items, making a 30-item Partnership Development Process Assessment (PDPA) Scale.

Next, the 30 items developed in the earlier process were subjected to content validity by a panel of experts. Eleven reviewers with public health expertise participated in this part of the study: six public health activists and five public health researchers with special interests in interactions and partnerships between public health nurses and community-based organizations. A content validity index test was used to compute and analyze the I-CVI, the S-CVI/Ave. (Polit and Beck, 2012). The experts were asked to score each of the thirty items on a 4-point scale $(1$ = unimportant, 2 = neither unimportant nor important, 3 = important, 4 = highly important) and to provide comments or suggestions to improve clarity. The I-CVI of less than 0.8 was the exclusion criterion. The S-CVI /Ave of more than 0.9 was the standard for establishing excellent content validity (Polit and Beck, 2012). Items were then revised according to comments from the reviewers. None of the 30 items in the PDPA Scale was deleted in the CVI analysis. Twelve items were revised following comments from the experts. 
Pilot test. A national postal survey, using a questionnaire and the new assessment scale, was conducted to determine the scale's internal structure and reliability, and to explore how it correlated with other measures. The sample was public health nurses who were interacting with community-based organizations and their recruitment sites were all of 1,742 local governmental public health offices throughout Japan; these offices are hubs for public health nursing in the surrounding community. Two copies of the questionnaire and the scale were given to office managers to disseminate to nurses who had direct interactions with local community organizations, asking every survey participant could receive the study information, the questionnaire and scale. From the 3,584 questionnaires distributed, 949 were returned. Of the returned surveys, 901 were included for analysis, while 48 were excluded due to missing data.

Ethics. All phases of this study were reviewed and approved by the Ethical Review Board of Kyushu University (Grant Number: 23-136, 24-200).

\section{Measures}


In the national survey, the questionnaire included the 30 items of the Partnership

Development Process Assessment (PDPA) scale devised in the preceding process, the details of

participants including age, gender, years of work experience, education level, current position

and responsibilities, the area and population in which they worked, and the Network

Establishment Practices (NEP) scale. We used the NEP scale to measure criterion validity. The

NEP scale has been developed in Japan and has 21 items. It has been tested for validity and

reliability nationwide (Cronbach’s alpha $=0.915$; Koshida and Morita, 2012). Each of the thirty

items in the PDPA scale was scored on a 4-point scale ( $0=$ not achieved, $1=$ hardly achieved, 2

= partly achieved, 3 = fully achieved) to assess PHNs’ partnership development activities.

Appropriate network establishment is considered the foundation for good partnerships (Chrisman

et al., 2002). Thus, we expected a strong correlation between the NEP and PDPA scores.

\section{Analytic Strategy}

The initial item development process included a content validity index test. Item analysis, validity, and reliability testing were performed in the following process involving the national survey. SPSS Statistics Version 20.0 for Windows was used to perform statistical analyses. Item 
analysis included analysis of ceiling and floor effects using the standard deviation and mean

value, analysis of normality using a probability-probability plot, analysis of the item-total

correlation and correlations between each item, and a good-poor analysis to analyze the results

of the multiple choice questions. Items with a correlation of 0.7 or higher were reviewed to

exclude duplicated content. Through good-poor analysis, items were grouped into either a lower

score group or a higher score group according to participants’ mean scores.

Construct validity was tested using factor analysis, and the analysis of the criterion

validity was done by calculating the correlation coefficients between the tool and each external

variable. The exploratory factor analysis employed the main factor (or common) method. Items

and factors with eigenvalues over 1 were extracted. Items with factor loadings of more than 0.4

on only one factor were extracted. Factors were identified and named according to the items

grouped within them.

Reliability was tested using split-half method, confidence coefficients, Cronbach’s alpha

coefficients of each factor after the exclusion of one item, and Cronbach's alpha coefficients for

each factor. 


\section{Results}

The 10 public health nurses involved in the first phase of the study who received the

qualitative semi-structured interviews to develop items were exclusively women. The mean age

was 44.9 years ( $\mathrm{SD}=10.5$, range: $30-60)$. The sample population covered five prefectures.

Participants worked for local governments of communities with populations between 18,000 and

670,000. The average interview time was 77 minutes (range 57-92 minutes).

Two hundred and sixty-six relevant quotes regarding partnership development process

were identified from the qualitative coding data. Further data processing was performed to create

27 potential items for the scale. A more extensive item review process, which included a

literature review and expert consultations, yielded a final selection of 30 items. These items were

organized into five topic areas: activities regarding sharing information on community health

issues with community-based organizations, activities to establish accountability with

community-based organizations, activities to evaluate partnership progress, platform activities to

encourage involvement of community-based organizations, and activities to ensure integrated

approaches with local authorities.

Next, a panel of experts evaluated the items with the Index of Content Validity. The 
I-CVI was between 0.82-1.0. None of the 30 items was deleted by the exclusion criterion. The

S-CVI/Ave was 0.93. The 30-item PDPA scale achieved the standard for establishing excellent content validity.

Table 1 shows the demographic characteristics of the national postal survey sample

included $98.1 \%$ women and $1.9 \%$ men. It also included the national data of public health nurses and population size of the municipality for comparison. The responders were more experienced professionals, of in their 40s and 50s, than the average age of public health nurses. At the same time, their geographical and epidemiological characteristics were similar to the national data. Table 2 shows the results of the item analysis of the 30 items. Mean values ranged between 1.00 and 2.28, with standard deviations between 0.74 and 1.04. Item 19 was deleted because of a ceiling effect, but no other items showed either a ceiling or a floor effect. Results of analysis of normality showed normality of the obtained data.

After the deletion of Item 19, the remaining 29 items were examined using analysis of item-total correlations and correlations between items, and good-poor analysis. Each item-total correlation coefficient was between 0.55 and 0.76 . Five item correlations had coefficients greater 
than $0.7: 2$ and 3, 7 and 8, 14 and 15, 27 and 29, and 29 and 30. The contents of these highly

correlated items were reviewed, and three items (Item 2, 14 and 29) were deleted due to

duplicate content. This left 26 items for further examination.

Next, good-poor analysis and t-tests were performed to further confirm the appropriateness of the items. Among the 901 participants surveyed, the mean score was 48 for the 26 items. Thus, we divided participants into subgroups of those with higher scores $(n=442$, score 48 and over) and those with lower scores ( $\mathrm{n}=459$, score less than 48). There was a significant difference between the two groups for every item $(p<0.01)$.

Factor analysis was then conducted on the 26 remaining items to examine construct validity. An exploratory factor analysis with a main factor method and promax rotation resulted in the extraction of four factors. Three items-Items 1, 20, and 21—were deleted because they had high factor loadings on more than one factor. Table 3 showed the results of factor analysis. The variance contribution ratios of the four factors were $48.3 \%, 4.0 \%, 3.4 \%$, and $2.8 \%$, respectively. The cumulative contribution ratio was $58.4 \%$. The mean ratio of the twenty-three items was $36.3 \%(\mathrm{SD}=14.9)$.

Each factor was summarized and named according to the contents of its items: activities 
to share roles to manage community health issues (Factor 1); platform activities to support

partnership (Factor 2); activities to evaluate partnership practices (Factor 3); and activities to

share information regarding community health issues (Factor 4).

We then conducted reliability testing on the four factors and 23 items. The confidence

coefficient, as determined by the split-half method, was 0.91 (Spearman Brown formula). The

Cronbach’s alpha coefficient for the overall scale was 0.95, while Cronbach’s alpha coefficients

were $0.92,0.84,0.88$, and 0.82 for Factors 1,2 , 3, and 4, respectively. There was high internal

consistency.

Table 4 shows the results of the correlation analysis of our PDPA scale with the external

variable: the NEP scale. The mean scores were $39.44(\mathrm{SD}=15.4)$ for the PDPA scale, $53.3(\mathrm{SD}=$

14.2) for the NEP scale, There were moderate correlations between the PDPA scale (the total and

factor scores) and the NEP scale ( $\mathrm{r}=0.54 ; p<.001)$.

\section{Discussion}

The PDPA scale developed in this study for public health nurses in Japan contains 23

items that are categorized into four factors. Reliability testing confirmed that the assessment 
scale had high split-half reliability, confidence coefficients, and internal consistency, indicating that the scale was sufficiently reliable. The scale was also successfully validated through the CVI, Factor Analysis, and correlation with an existing instrument. These results demonstrate that the assessment scale is valid and reliable for measuring effective partnership development.

Use of existing assessment scales such as the Australian Tool (VicHealth, 2011) has been discussed at the preliminary stage of the study. It was considered that, as a principle, the approach to partnership development where existing assessment scales are useful is top-down, with defined politics and strategies are established prior to following activities of partnership development. On the contrary, systems and approaches in Japan are rather bottom-up, where existent elements and activities are to be cultivated and evolved into partnerships. Hence, it was decided to develop a new scale to suit unique aspects of partnership development process in Japan.

The newly developed scale has factors and items that are similar to those in the strategic development of partnership in Western countries (Keller, Strohschein, Schaffer, \& Lia-Hoagberg, 2004), which includes the sharing of information, delegation of roles and responsibilities, action, and reflection. However, further exploration of factors and items identified areas that are 
exclusive in the PDPA scale, indicating distinctions between strategic and informal processes.

Factor 1, activities to share roles to manage community health issues, included items highlighting informal processes, such as sharing information about community health issues and characteristic activities (including strengths and weaknesses), and keeping updated through discussions and communication. Activities to establish a relationship and empower community-based organizations appear to have significance in PHNs' roles in Japan, while strategic processes commonly start from evidence-based policymaking and planning (Buckett, Williams, \& Wildgoose, 2011), which require human capital and funding resources (Dowling et al., 2004). In Japan, PHNs have enriched these resources lacking in community-based organizations (Yoshioka-Maeda et al., 2006) and their activities to promote partnership practices, improve quality of practices, network establishment, and invite others to take part in policymaking were considered important. They are also essential in order to achieve and maintain optimal work relationships, encouraging communication and understanding of individuals/families/community organizations to improve their roles (Courtney et al., 1996) and establish cooperation (Buckett et al., 2011).

Factor 2, platform activities to support partnership, included activities that are 
fundamental in order to establish an integrated approach from governmental organizations to promote public health partnerships with community-based organizations (Perkins, Smith, Hunter, Bambra, \& Joyce, 2010). PHNs are responsible and accountable for such activities in the Japanese public healthcare system, as platform work across all sectors involved in public health in local authority and bridging between governmental organizations and community-based organizations. These activities require to be receptive and ongoing in essence. The significance of these work for PHNs in Japan is implied as it is listed as one factor.

The third factor concerned assessment. The Institute of Medicine (IOM2002) reported that assessment was one of core functions of public health sectors from all levels of governmental bodies. It was also reported that public health nurses had a role and responsibility in the assessment process (American Public Health Association public Health nursing section, 1996). Factor 3, activities to evaluate partnership practices, included activities to monitor and assess progress and outcomes, publishing reports, and utilizing reports in writing business plans. Assessments involving public health nurses and community-based organizations, as well as published assessment reports, have been shown to be important for the partnership process between governmental bodies and community-based organizations (Navruzov, Rose, \& Shelley, 
2000). Transparency of practices was also important. The scale was designed for any stage of partnership development. It was expected to encourage the Plan-Do-Check-Action cycle (Baker et al, 2008) and, as a result, promote partnership practices.

Factor 4, activities to share information regarding community health issues, included activities that provide easy access to information about community health issues and the limitations of governmental services. One study focused on the responsibilities of health sectors to provide transparent information to the public (El Ansari, Phillips, and Zwi, 2004). The results of our study also showed another aspect regarding sharing information, which is recognizing one's own weaknesses and openly exchanging information about both positive and negative aspects of practices in order to build successful partnerships and share roles and responsibilities.

The PDPA scale includes items for assessing continuing activities such as updated information and open discussions, and efforts to involve all sectors of local authority in public health. These are important factors at any stage of partnership development, which highlights versatility of the scale. Future research is facultative to examine partnership development using the PDPA scale for its revision and in-depth analysis of partnership process, in consideration of a huge diversity in the nature of partnerships and their aims, structures and activities due to 
significant inequalities in constitution of communities and ever changing societies.

There were some limitations in this study. First, more consideration about sample recruitment could have improved a response. It was an indirect recruitment through office managers, not a direct recruitment. However, the number of the responders was over 900, and they were not hugely biased when compared with the national data (Table 1). Furthermore, this was a nationwide survey distributed to all the local public health offices in Japan aiming to examine partnership development process in which public health nurses are involved in common practice. Second, solo external variable was used for the analysis of criterion validity. Additional work is required to consolidate its criterion-related validity and to further examine the items of the PDPA scale.

Despite the limitations, the study has substantial strengths, including the systematic process through which the scale was developed; qualitative interviews for generating item content, a literature review and expert consultations to establish content validity, and a field test for construct validity. It could be useful at each stage, as a starting point for partnership development among agencies, to monitor and document partnership involvement, for administrators to improve partnership among agencies. Although further development and 
validation work on the PDPA scale is required, practical use of the scale is feasible to provide guidance for administrators involved in partnership among agencies to prepare conceptual and measurement foundation in partnership development and to monitor, document and revise process and activities for the improvement of partnership. 


\section{References}

American Public Health Association, Public Health Nursing Section. (1996). The definition of role of public health nursing. Washington, DC: American Public Health Association.

Baker, G. A., Mackintosh-Murray, C., Porcellato, L., Dinne, K., Stelmacovich, K., \& Born, K. (2008). High performing health systems: Delivering quality by design. Toronto: Longwoods Publishing, 279-291.

Buckett, K., Williams, C., \& Wildgoose, D. (2011, October). Health in all policies: South Australia’s country case study on action on the social determinants of health. Paper presented at the World Conference on Social Determinants of Health, Brazil.

Chrisman, N. J., Senturia, K., Tang, G., \& Gheisar, B. (2002). Qualitative process evaluation of urban community work. Health Education \& Behavior, 29(2), 232-228.

Courtney, R., Ballard, E., Fauver, S., Gariota, M., \& Holland, L. (1996). The partnership model: Working with individuals, families, and communities toward a new vision of health. Public Health Nursing, 13(3), 177-186.

Dowling, B., Powell, M., \& Glendinning, C. (2004). Conceptualising successful partnerships. Health \& Social Care in the Community, 12(4), 309-17. 
El Ansari, W., Phillips, C. J., \& Zwi, A. B. (2004). Public health nurses’ perspectives of collaborative partnerships in South Africa. Public Health Nursing, 21(3), 277-286.

Funashima, N. (2009). Kangozisen no kyouiku notameno sokuteiyougu fairu kaihatukatei kara katuyou no zissennmade [The Application of Measurement Tools to Enhance the Quality of Nursing Care and Education], Tokyo: Igakusyoin.

Institute of Medicine (IOM) (November 2002). The future of the public's health in the 21st century. Washington, DC: The National Academies Press, pp. 96-101.

Kegler, M. C., Norton, B. L., \& Aronson, R. E. (2008). Strengthening community leadership: Evaluation findings from the California Healthy Cities and Communities Program. Health Promotion Practice, 9(2), 170-179.

Keller, L. O., Strohschein, S., Schaffer, M. A., \& Lia-Hoagberg, B. (2004). Population-based public health interventions: Innovations in practice, teaching, and management. Part II. Public Health Nursing, 21(5), 469-87.

Koshida, M., \& Morita, T. (2012). Japanese development and testing of the Network Establishment Practices Scale for community and public health nurses. Nursing and Health Sciences, 15(1), 22-30. 
Lincoln Y.S., Guba E.G., (1985). Naturalistic Inquiry. California: SAGA Publications.

Ministry of Health, Labour \& Welfare (2012). Basic Guidelines on the Promotion of Community

Health Measures, Retrieved March 31, 2014 from:

http://www.pref.niigata.lg.jp/HTML_Simple/961/648/kunituuti.pdf\#search='\%E5\%9C\%

B0\%Е5\%9F\%9F\%E4\%BF\%9D\%E5\%81\%A5\%E5\%AF\%BE\%E7\%AD\%96\%Е3\%81\%

AE\%E6\%8E\%A8\%Е9\%80\%B2\%E3\%81\%AB\%E9\%96\%A2\%E3\%81\%99\%E3\%82\%8

В\%Е5\%9F\%ВА\%Е6\%9С\%AC\%Е7\%9A\%84\%Е3\%81\%АA\%Е6\%8С\%87\%Е9\%87\%9

D'.

Ministry of Health, Labour \& Welfare (2012). National Data of Public Health Nurses in Japan.

Retrieved September 22, 2014 from:

http://www.mhlw.go.jp/toukei/saikin/hw/eisei/12/dl/h24_hojyokan.pdf

Ministry of Internal Affairs and Communications. Statistics Bureau (2010). Population size of

the municipality. Retrieved September 22, 2014 from:

http://www.stat.go.jp/data/nihon/02.htm , 2-8

Navruzov, Y., Rose, A., \& Shelley, W. (2000, April). Role of partnership in modern local

government. Paper presented at the Eighth Annual Conference of the Network of 
Institutes and Schools of Public Administration in Central and Eastern Europe

(NISPAcee), Budapest.

O’Mara-Eves, Brunton, McDaid Oliver, Kavanagh, Jamal, Matosevic, Harden, \& Thomas.

(2013). Community engagement to reduce inequalities in health: a systematic review,

meta-analysis and economic analysis, Retrieved August 03, 2014 from:

http://www.journalslibrary.nihr.ac.uk/_data/assets/pdf_file/0006/94281/FullReport-phr0

1040.pdf

Perkins, N., Smith, K., Hunter, D. J., Bambra, C., \& Joyce, K. (2010). 'What counts is what works'? New labour and partnerships in public health. Policy \& Politics, 38(1), 101-117,

Polit, D. F., \& Beck, C. T. (2012). Nursing Research Generating and assessing Evidence for Nursing Practice. Lippincott Williams \& Wilkins.

Public Health Agency of Canada (2008). Core competencies for public health in Canada release

1.0. Retrieved March 31, 2014 from:

http://www.phac-aspc.gc.ca/php-psp/ccph-cesp/pdfs/zcard-eng.pdf”

Suzuki, Y., Omori, J., Sakai, M., Anzai, H., Kobayashi, K., Miyazaki, M., Ozaki, A., \& Asahara, K. (2008). Nihon no pa-tona-sippu gainen bunseki [Partnership in community health 
activities in Japan: concept analysis]. Journal of Japan Academy of Community Health Nursing, 12(1), 44-49.

World Health Organization (2010). The Adelaide Statement on Health in All Policies. Retrieved March 31, 2014

from: http://www.who.int/social_determinants/hiap_statement_who_sa_final.pdf\#search ='WHO+The+Adelaide+Statement+on+Health+in+All+Policies+2008'

Yamashita, J., (2013). Citizen Participation or Low-Cost Care Providers? Welfare Non-profit Organisations in Japan, Social Science Japan Journal, 16 (1), 45-62.

Yoshioka-Maeda, K., Taguchi, K., Murashima, S., Asahara, K., Anzai, Y., Arimoto, A., Miyazaki, T., Magilvy, J. K. (2006). Function and practice of public health nursing in Japan: A trial to develop the Japanese Purpose-Focused Public Health Nursing Model. Journal of Nursing Management, 14(6), 483-489.

VicHealth (2011). The partnerships analysis tool. Retrieved March 31, 2014 from http://www.vichealth.vic.gov.au/Publications/VicHealth-General-Publications/Partn erships-Analysis-Tool.aspx 
Table 1

Demographic profile of the participants $(n=901)$ and National Data

\begin{tabular}{|c|c|c|}
\hline Characteristic & \multicolumn{2}{|l|}{$\mathrm{N}(\%)$} \\
\hline \multicolumn{2}{|c|}{ Demographic profile of the participants } & National Data *, ** \\
\hline \multicolumn{3}{|l|}{ Sex } \\
\hline Female & $884(98.1)$ & $46,549(98.5)$ \\
\hline Male & 17(1.9) & $730(1.5)$ \\
\hline \multicolumn{3}{|l|}{ Age(years) } \\
\hline$\leq 29$ & 83(9.2) & $7,553(16.0)$ \\
\hline 30-39 & $241(26.7)$ & $14,584(30.8)$ \\
\hline $40-49$ & $317(35.2)$ & $13,539(28.6)$ \\
\hline $50-59$ & $257(28.5)$ & $9,365(19.8)$ \\
\hline $60 \leq$ & $3(0.3)$ & $2,238(4.7)$ \\
\hline \multicolumn{3}{|c|}{ Population size of the municipality belongs } \\
\hline$\leq 10,000$ & 172(19.1) & $482(27.5)$ \\
\hline$! 0,000-30,000$ & 194(21.5) & $462(26.4)$ \\
\hline $30,000-50,000$ & $135(15.0)$ & $245(14.0)$ \\
\hline $50,000-100,000$ & 191(21.2) & 272(15.5) \\
\hline $100,000-300,000$ & $146(16.2)$ & 205(11.7) \\
\hline $300,000-1000,000$ & $55(6.1)$ & $73(4.2)$ \\
\hline $1000,000 \leq$ & $8(0.9)$ & $12(0.7)$ \\
\hline
\end{tabular}

\footnotetext{
*National Data of Public Health Nurses in Japan (2012) (Sex, Age); published by Ministry of Health, Labour \& Welfare). ${ }^{* *}$ National Data of Population size of the municipality (2010); published by Ministry of Internal Affairs \& Communications, Statistics Bureau.
} 
Table 2

Item Analysis of the Partnership Development Process Assessment Scale $(n=901)$

\begin{tabular}{|c|c|c|c|c|}
\hline Mean & $\begin{array}{l}\text { Standard } \\
\text { Deviation } \\
\text { (SD) }\end{array}$ & $\begin{array}{l}\text { Inter-item } \\
\text { correlation }\end{array}$ & $\begin{array}{l}\text { I-T } \\
\text { correlation }\end{array}$ & $\begin{array}{l}\text { Good-Poor } \\
\text { Analysis }\end{array}$ \\
\hline
\end{tabular}

Activities to share information regarding community health issues with community-based organizations

1 I know community health issues which

$1.83 \quad 0.73$

$0.35-0.60$

$0.65^{* *}$

0.74

community-based organizations are aware of

and positive aspects of the community.

2 I know whether community-based

$1.83 \quad 0.80$

$0.29-0.73 \quad 0.64^{* *}$

0.81

organizations have administration enabling

steady activities in order to improve

community health outcomes.

3 I know details of activities that

$2.00 \quad 0.75$

$0.25-0.73$

$0.63^{* *}$

0.75

community-based organizations provide to

improve community health outcomes.

4 Information that public health nurses hold

$1.55 \quad 0.86$

$0.30-0.68$

$0.61^{* *}$

0.81

regarding community health issues and

positive aspects of the community is easily

accessible to community-based organizations.

5 Information regarding community health

$1.74 \quad 0.82$

$0.32-0.68$

$0.67 * *$

0.83

issues and positive aspects of the community

are reported to community-based

organizations.

$6 \quad$ Information regarding public health nursing

$1.49 \quad 0.84$

$0.35-0.61$

$0.68 * *$

0.90

practices to improve public health in areas out

of nurses' reach is reported to

community-based organizations.

\section{Activities to establish accountability with community-based organizations}




Sats

Consultations are held with community-based

organizations to discuss community health

issues and positive aspects of the community.

8 Information regarding strengths and

weaknesses of the practices of both public

health nursing and community-based

organizations are shared. Both practices

collaborate in activities to improve

community health.

$9 \quad$ Both public health nurses and

community-based organizations understand

the characteristics of their cooperative and

individual activities ${ }^{*} 1,{ }^{*} 2$.

10 Regular meetings are organized between both

1.60

0.95

parties (public health nursing practices and

community-based organizations) to discuss

community health issues and their roles and

activities.

11 Community-based organizations are involved

1.46

0.96

0.35-0.65

$0.73 * *$

1.11

from the initial consultation to initiate

cooperation ${ }^{\#} 1$ to share roles and activities.

12 Activities to support individual activities ${ }^{\#} 2$,

1.67

0.93

$0.29-0.61$

$0.67 * *$

0.92

such as promotions, providing venues,

collaborations, sponsoring, are organized

with community-health organizations. 


\section{Activities to evaluate partnership practices}

13 Roles and activities are reviewed routinely

$1.49 \quad 0.87$

0.35-0.69

$0.78^{* *}$

1.05

with community-based organizations.

14 Meetings are held to discuss an assessment

$1.09 \quad 0.84$

0.33-0.76

$0.72 * *$

0.95

program for checking activities to achieve

their goals.

15 Process assessment of shared activities with

$1.09 \quad 0.84$

$0.34-0.76$

$0.73^{* *}$

0.95

community-based organizations are arranged,

such as exchange of information, sharing

roles, planning, activities, appraisals, and

assessment programs.

16 Interim and long-term monitoring are

$1.00 \quad 0.81$

$0.30-0.65$

$0.68 * *$

0.93

arranged to evaluate outcomes of partnership

activities in light of improvement in

community health.

17 Reports from evaluation of partnership

$1.50 \quad 0.92$

$0.36-0.67$

$0.75^{* *}$

1.08

activities are utilized in writing business plans

for the following year.

18 Reports from evaluation of partnership

$1.11 \quad 0.88$

$0.33-0.67$

$0.70 * *$

0.96

activities are officially published to promote the activities.

\section{Platform activities to encourage involvement of community-based organizations}
19 I sincerely respond to enquiries from
$2.28 \quad 0.76$
$0.30-0.48$
$0.63^{* *}$
0.75
community-based organizations regarding
community health issues and activities to 


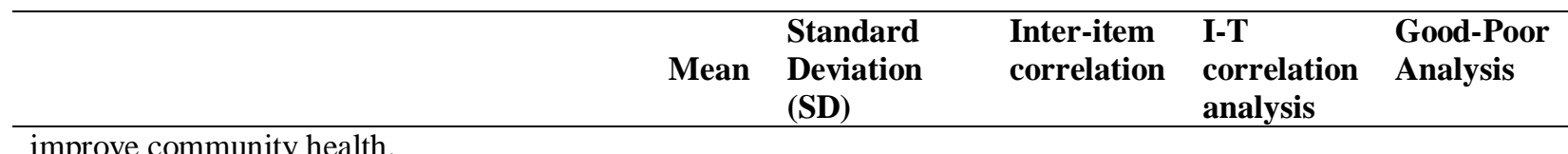

20 Efforts are made to learn of activities of

$\begin{array}{lllll}1.36 & 0.86 & 0.31-0.50 & 0.59 * * & 0.83\end{array}$
community-based organizations practicing in areas where there are limited public health nursing practices available.

21 Mutual understanding is achieved regarding risks and risk management of possible adverse events in partnership activities, such as breaching confidentiality.

22 Activities such as training, seminars, and $0.32-0.59$ conferences are organized to improve the quality of the partnership.

23 Supports to establish network between $1.44 \quad 0.93$ $0.34-0.59$ community-based organizations are achieved.

24 The aim to fund partnership activities is achieved through business plans from national, regional, and local organizations.

25 Involvement of community-based $1.64 \quad 0.95$ $0.36-0.55 \quad 0.67 * *$ organizations in policymaking process regarding public health and social care is appropriately arranged.

\section{Activities to ensure integrated approaches from local authority}
26 Aims of partnership from the perspective of
$1.52 \quad 0.88$
$0.36-0.58$
$0.72^{* *}$
0.98 local authorities and related policies are clear.
27 Discussions between public health nurses are
$1.77 \quad 0.89$
$0.37-0.65 \quad 0.69 * *$
1.01 


\begin{tabular}{lllll}
\hline & Mean & $\begin{array}{l}\text { Standard } \\
\text { Deviation } \\
\text { (SD) }\end{array}$ & $\begin{array}{l}\text { Inter-item } \\
\text { correlation }\end{array}$ & $\begin{array}{l}\text { I-T } \\
\text { correlation } \\
\text { analysis }\end{array}$ \\
\hline organized to explore possible advantages of & & $\begin{array}{l}\text { Good-Poor } \\
\text { Analysis }\end{array}$ \\
\hline
\end{tabular}

partnership with community-based

organizations according to analyses of

community health issues.

28 Discussions across all sectors involved in public health in local authority are organized to examine objectives of partnership

29 Interactions and mutual understanding of $1.37 \quad 0.83$

$0.27-0.81$

$0.60^{* *}$

0.82

roles of all sectors involved in public health in local authority are achieved.

30 Shared information across all sectors $1.37 \quad 0.85$ $0.25-0.81$

$0.61^{* *}$

0.85 involved in public health in local authority is available so that staff can utilize a uniform approach to community-based organizations.

Note. I-T = Item-Total; ${ }^{* *} p<.01$ (both sided)

${ }^{\# 1}$ Cooperative activities: activities that both parties participate in and share workload.

\#2 Individual activities: activities that each party operates individually using their advantages without sharing workload. 


\section{Table 3}

Factor Analysis of the Partnership Development Process Assessment Scale (4 factors, 23 items, total overall alpha index $=0.95$ )

\section{Factor loading with scale}

\section{Factor 1 Factor 2 Factor $3 \quad$ Factor 4}

\section{Factor 1 Activities to share roles to manage community health issues $\alpha=0.92$}

$$
\text { Both public health nurses and community-based organizations }
$$

0.818

$$
-0.084
$$

understand the characteristics of their cooperative and individual

$$
\text { activities }{ }^{\#} 1,{ }^{*} 2 \text {. }
$$

12 Activities to support individual activities, such as promotions, providing venues, collaborations, sponsoring, are organized with community-health organizations.

11 Community-based organizations are involved from the initial consultation to initiate a cooperation to share roles and activities. health nursing practices and community-based organizations) to discuss community health issues and their roles and activities.

8 Information regarding strengths and weaknesses of the practices

$\begin{array}{llll}0.610 & -0.012 & 0.001 & 0.275 \\ 0.587 & 0.043 & 0.277 & -0.054\end{array}$

13 Roles and activities are reviewed routinely with

0.587 community-based organizations.

3 I know details of activities that community-based organizations

$-0.017$

$-0.027$ provide to improve community health.

22 Activities such as training, seminars, and conferences are

$0.551 \quad 0.360 \quad-0.172 \quad-0.007$
organized to improve quality of partnership.

23 Supports to establish networks between community-based organizations are achieved.

7 Consultations are held with community-based organizations to 


\section{Factor loading with scale}

$\begin{array}{llll}\text { Factor } 1 & \text { Factor } 2 & \text { Factor } 3 & \text { Factor } 4\end{array}$

community.

25 Involvement of community-based organizations in

$\begin{array}{lll}0.407 & 0.371 & 0.002\end{array}$

$-0.047$

policymaking process regarding public health and social

care is appropriately arranged.

\section{Factor 2 Platform activities to support partnership $\alpha=0.84$}

0.811

0.013

0.120

local authority are organized to examine objectives of

partnership.

Shared inform

local authority is available so that staff can utilize a uniform

approach to community-based organizations.

27 Discussions between public health nurses are organized to

$\begin{array}{lll}-0.006 & 0.679 & -0.023\end{array}$

0.169

explore possible advantages of partnership with

community-based organizations according to analyses of

community health issues.

26 Aims of partnership from the point of local authority and related

0.161

0.594

0.080

$-0.021$

policies are clear.

24 The aim to fund partnership activities is achieved through

0.349

0.405

0.077

$-0.191$ business plans from national, regional, and local organizations.

\begin{tabular}{|c|c|c|c|c|c|}
\hline & Factor 3 Activities to evaluate partnership practices $\alpha=0.8$ & & & & \\
\hline 18 & $\begin{array}{l}\text { Reports from evaluation of partnership activities are officially } \\
\text { published to promote the activities. }\end{array}$ & -0.075 & 0.074 & 0.796 & 0.038 \\
\hline 16 & $\begin{array}{l}\text { Interim and long-term monitoring are arranged to evaluate } \\
\text { outcomes of partnership activities in light of improvement in }\end{array}$ & -0.077 & 0.029 & 0.790 & 0.070 \\
\hline
\end{tabular}




\section{Factor loading with scale}

Factor 1 Factor 2 Factor $3 \quad$ Factor 4

15 Process assessment of shared activities with community-based

$-0.047$

0.699

$-0.007$

organizations are arranged, such as exchange of information,

sharing roles, planning, activities, appraisals, and assessment

programs.

17 Reports from evaluation of partnership activities are utilized in

0.225

0.065

0.589

$-0.021$ writing business plans for the following year.

Factor 4 Activities to share information regarding community health issues $\alpha=0.82$

$5 \quad$ Information regarding community health issues and positive $\quad \begin{array}{llll}0.062 & 0.033 & -0.034 & 0.816\end{array}$

aspects of the community are reported to community-based

organizations.

$4 \quad$ Information that public health nurses hold regarding community $\quad \begin{array}{llll}-0.118 & 0.100 & 0.103 & 0.707\end{array}$

health issues and positive aspects of the community are easily

accessible to community-based organizations.

$6 \quad$ Information regarding public health nursing practices to improve $\begin{array}{llll}0.321 & 0.008 & 0.020 & 0.452\end{array}$

public health in areas out of nurses' reach is reported to

community-based organizations

Load sum of squares after the rotation

$\begin{array}{llll}11.1 & 0.9 & 0.8 & 0.6\end{array}$

Contribution ratio (\%)

48.3

4.0

3.4

2.8

Cumulative contribution ratio (\%)

48.3

52.2

55.7

58.4

Factor correlation Factor $\mathbf{1}$

- $\quad 0.692^{* *}$

$0.747^{* *}$

$0.672 * *$

Factor 2

— $0.654^{* *} \quad 0.578^{* *}$

Factor 3

- $\quad 0.573^{* *}$

Factor 4

** $\quad p<.01$ (both sided)

Factor extraction method: Main factor method, Rotation method: Promax method with Kaiser normalization 
Bold figures: Factor loadings above 0.4

23 items from initial 30 items

${ }^{\# 1}$ Cooperative activities: activities that both parties participate in and share workload.

\#2 Individual activities: activities that each party operates individually using their advantages without sharing workload. 
Table 4

Analysis of Correlation with Network Establishment Practices Scale and Partnership

Development Process Assessment Scale

\begin{tabular}{|c|c|c|c|c|c|}
\hline \multirow[t]{2}{*}{ External Variables } & \multicolumn{5}{|c|}{ Pearson’s correlation coefficient } \\
\hline & & Factor 1 & Factor 2 & Factor 3 & Factor 4 \\
\hline & Overall & $\begin{array}{l}\text { Activities to share } \\
\text { roles to manage } \\
\text { community health } \\
\text { issues }\end{array}$ & $\begin{array}{l}\text { Platform } \\
\text { activities to } \\
\text { support } \\
\text { partnership }\end{array}$ & $\begin{array}{l}\text { Activities to } \\
\text { evaluate } \\
\text { partnership } \\
\text { practices }\end{array}$ & $\begin{array}{l}\text { Activities to share } \\
\text { information } \\
\text { regarding community } \\
\text { health issues }\end{array}$ \\
\hline Network Establishment & $0.525^{* *}$ & $0.460^{* *}$ & $0.500^{* *}$ & $0.413^{* *}$ & $0.475^{* *}$ \\
\hline \multicolumn{6}{|l|}{ Practices Tool } \\
\hline$[\mathrm{Av}=53.3, \mathrm{SD}=14.2]$ & & & & & \\
\hline
\end{tabular}

$* * p<.01$ (Both sided) 


\section{日本における保健師の地域組織とのパートナーシップ構築 プロセス評価尺度の開発}

\section{要旨}

目的 : 本研究の目的は、保健師による地域組織とのパートナーシップ構築プロセス評価尺度

（Partnership Development Process Assessment Scale 以後 PDPA 尺度と表記する）の信頼性・妥当 性を検討し、尺度を開発することである。PDPA 尺度は、日本における保健師の地域組織とのパート ナーシップ構築プロセスを評価するために必要である。

研究方法: 研究は三段階で行った。第一段階として、地域組織とパートナーシップを構築している 保健師 10 名に半構造化面接を実施し尺度の項目を生成した。第二段階は、専門家を対象に第一段階 の面接データの分析から得られた 30 項目に関する質問紙調查をおこない、項目の内容的妥当性の検 討及び表現の洗練を行った。第三段階は、地域組織とパートナーシップ構築活動を行っている全国市 町村の保健師を対象とした質問紙郵送調査を行い尺度の信頼性と妥当性の検討を行った。

測定 : PDPA 尺度の、項目の内容の妥当性と既存の尺度との相関の分析を用いた妥当性及び信頼性の 検討

結果：「健康課題に対する役割共有にむけた取り組み」、「パートナーシップ推進に向けた基盤整備」、 「パートナーシップの評価」「健康課題に関する情報の発信」の 4 つの因子から構成された 23 項目 の尺度を開発した。

結論 : PDPA 尺度はパートナーシップの開発活動を評価するための保健師のために信頼性・妥当性が あると確認された。 


\section{研究の背景}

現代の社会事情やライフスタイルは公衆衛生に新たな課題をもたらしている。日本では高齢化と出 生率減少が人口構造に顕著な変化を起こしており、結果として保健福祉サービスや慢性疾患管理の需 要が急速に増大している。また、長期化する不景気による金融不安や所得格差は、既に存在する健康 格差を広げる一方である。このような現状において、個人だけでなく地域の保健福祉への関心とニー ズは益々増大してきている。

日本の公衆衛生サービスは歴史的に地方自治体ごとに管理されている。日本の市町村保健師は保健 所・保健センターに属し、担当地区で健康増進に関する活動を実践する役割と共に、保健所・保健セ ンターの運営にも携わっている。保健師の役割の一つとして、地域への活動や地域組織とのパートナ ーシップの支援の促進がある。保健師は、地域住民と直接関わる業務を通じて住民や地域組織との信 頼関係を築いていくとともに、情報収集や地域のアセスメントを行い、地域の保健福祉に関わる問題 解決のための事業計画立案と実施に携わっている(Yoshioka-Maeda, Taguchi, Murashima, Asahara, Anzai, Arimoto, Miyazaki, and Magilvy, 2006)。

地域の健康課題に応えるためには、地域の様々な組織が対話と協力を推進していくことが必要であ る。それは、地域の健康促進には、経済的、文化的、社会的な多様な要因が複雑にからみあっている ためである。ミッション、焦点、資金源等の特徵の異なる背景を持つ組織とのパートナーシップは、 健康上の成果を向上させるために有益である。そのため、The World Health Organization [WHO] (2010)は、行政の保健関係部署の新たな役割として、地域組織とのパートナーシップの構築ための枠 組みの検討や調整の役割を期待している。

パートナーシップとは、共通の目標を達成する為に、役割や責任を共有する関係を構築することで ある(Chrisman, Senturia, Tang, and Gheisar, 2002)。地域において、保健師と地域組織とのパート ナーシップが構築されることで、お互いが学びあい、活動に責任の自覚が芽生え、個人や組織そして 地域がエンパワメントし、保健サービスの重複及び偏りの減少や保健サービスの利便性の改善につな 
がる(O’Mara-Eves, Brunton, McDaid Oliver, Kavanagh, Jamal, Matosevic, Harden, and Thomas, 2013)。

その為、パートナーシップは、公衆衛生に関わる専門職の実践に不可欠な知識・技術として位置づ けられている(Public Health Agency of Canada, 2008)。保健専門職は、地域に足を運び、地域組織 と協力し地域の健康上の課題を検討し、地域の組織の積極的な関与の為の方法の設計等のリーダーや ファシリテーターとして(Courtney, Ballard, Fauver, Gariota, and Holland, 1996)、健康課題の改善 にむけた戦略を開発する必要がある(Kegler, Norton, and Aronson, 2008)。日本において、保健師は、 地域保健の戦略の第一線の実践者および管理者として、地域のパートナーシップの構築に重要な役割 を担うことが期待されている。

効果的なパートナーシップに大きな影響を与える要因は、活動のプロセスである。そのプロセスと は、納得できる説明、相互のコミットメントと信頼関係の構築、評価活動である(Dowling, Powell, and Glendinning, 2004)。評価尺度は、パートナーシップ活動の評価改善する部分を計画にするために役立 つ。パートナーシップ構築活動を評価するものとして、オーストラリアの効果的なパートナーシップ 活動を反映した 7 つ因子をもつ 35 項目の評価尺度(VicHealth, 2011)が開発されている。

しかし、地域保健におけるパートナーシップのプロセスは、オーストラリア等の西欧と日本では 異なる。西欧では、公衆衛生の専門職による国家的な戦略プロセスを促進するための明確な科学的根 拠に基づいたねらいとターゲットが定められたパートナーシップ活動が展開されている。一方、日本 のパートナーシップは、身近で立場の異なる人々・機関と信頼し力をわかちあう関係をつくり、その 関係を確立することにより、公式なパートナーシップに発展させることに重点を置いている。

(Suzuki, Omori, Sakai, Anzai, Kobayashi, Miyazaki, Ozaki, and Asahara, 2008)。

日本で行われている既存の関係を発展させるパートナーシップ構築の過程は、明らかになっていな い。そのため、地方自治体と地域組織のパートナーシップ構築活動の改善が十分に行えず、地域社会 のニーズに対応した政策の戦略的アプローチの効果が得られにくい状況にある(Yamashita, 2013)。 
日本では、2012 年の厚生労働省から出された「地域保健対策の推進に関する基本的な指針」におい て、行政と地域組織とのパートナーシップの強化に対する取り組みが推進されており、この推進の上 で尺度の開発は急務である。

\section{研究目的}

本研究の目的は、日本の保健師が使用できるパートナーシップ構築活動プロセス評価尺度（PDPA） を開発することである。

\section{方法}

本研究は、項目の生成、内容的妥当性の検討、因子分析と基準関連妥当性及び信頼性の検討の三段階 で行った(Funashima, 2009)。

\section{【研究デザインと標本】}

\section{尺度項目の生成と内容的妥当性の検討}

新たな測定用具の項目の開発のために、市区町村保健師 10 名を対象にインタビュー調査をおこなった。 地域保健関連雑誌に掲載された保健師を対象者とした。対象者は全員、地域の健康課題解決むけた地域 組織と関係を構築した経験を持ち、インフォームドコンセントに関する合意書を提出した。

面接では、地域組織との関わりの経験の中で、パートナーシップの構築に向けた効果的な活動を想起し、 具体的に語ってもらった。[質問内容: 1)あなたが行ったパートナーシップにむけた具体的な活動を教えてく ださい。2)地域組織に対する保健師の活動の経緯(直接的な関わり前の準備、環境整備などの間接的な関 わり、活動後のフィードバック等)について、具体的に教えてください。3) 実際に取り組んだ地域組織への関 わり以外に、保健師の取り組みとして必要だと考えることに教えてください。］質問者から、広範な回答を得る ために、具体的な想起してほしいパートナーシップについて特定しなかった。 
インタビュー時に許可を得て録音したデータから書き起こした遂語録を作成した。遂語録から、保健師の 活動とその活動前後の取り組みが読み取れる単位ごとに、文章を切り取った。切り取った文章の文脈の意味 内容を検討し、抽象度をあげ、カテゴリー化と命名をおこなった(Lincoln and Guba, 1985)。そして、更にカテ ゴリーの特性を統合し、抽象化し命名した。分析過程で、文献検討と研究者による協議を行った。信頼性を 確保するために、意味内容の解釈が不明なものは、対象者 4 名に補充面接を電話で行い、意味内容を確認 し分析を続けた。研究者による分析結果は、対象者 10 名に文書にて提示し、インタビューで話した内容を反 映しているか否かについて意見を求め、文書にて回答を得た。インタビューの分析により、保健師の地域組 織とのパートナーシップ活動とその活動前後の取り組みについて、27 項目を抽出した。文献検討と研究者に よる協議の過程で、27 項目に3項目を追加し、30 項目の PDPA 尺度原案を作成した。

次に、項目の内容的妥当性の検討と表現の洗練のために、地域組織活動の実践活動を雑誌に投稿して いる保健師 6 名と、保健師の地域組織活動やパートナーシップに関する研究を行っている公衆衛生看護の 研究者 5 名の計 11 名を対象に質問紙調査を行った。

専門家に、30 項目の各項目の内容の重要性について、4 段階 (4=非常に重要、3=重要、2=どちらでもない、 1=重要でない)で評価を依頼し、項目の内容的妥当性指数 (以後 I-CVI と表記) と、尺度全項目の内容 的妥当性係数 (以後 S-CVI/Ave と表記)を算出した(Polit and Beck, 2012)。

I-CVI は、0.8 未満を項目の削除基準とした。尺度全項目の有効性は、S-CVI/Ave は、0.9 以上とした (Polit and Beck, 2012)。PDCA尺度の 30 項目は内容的妥当性の分析で削除基準に該当しなかった。また、 専門家の意見を元に、12 項目の表現を修正した。

\section{パイロットテスト}

尺度の信頼性、構成概念妥当性及び基準関連妥当性の検討のために、日本の全市町村 $(1,742) の$ 保健 師を対象とした郵送による無記名自記式の質問紙調査を行った。調査票 (研究目的を含んだ依頼文、回答 者の属性に関するアンケートと尺度) は、市町村の保健師管理者宛に 2 部送付し、地域組織に対する活動を 行っている保健師に配布してもらうように依頼した。3,584 通送付し、949 通の返送があり、その中で全項目に 
欠損のない 901 を有効回答として分析対象とした。

\section{倫理的配慮}

本調査の実施については、九州大学大学院医学系学府倫理審査委員会の承認[23-135、24-200]得 た。

\section{【測定用具】}

調査項目は、作成した PDPA 尺度原案、対象者の年齢・性別・保健師経験年数・最終学歴・現在の職位・ 活動形態、市町村の人口規模、ネットワーク形成実践技術尺度であった。ネットワーク形成実践技術尺度 （Network Establishment Practices scale 以後、NEP 尺度と表記）は、日本の文化の中で信頼性妥当性を確認 済(Cronbach’s $\alpha=0.915$; Koshida and Morita, 2012)の 21 項目の尺度である。PDPA 尺度原案は、保健師 自身の地域組織とのパートナーシップ構築活動を振り返り、行った活動が各項目にどの程度あてはまるのか を 4 段階(3とてもあてはまる 2 少しあてはまる 1 すこしあてはまらない 0 まったくあてはまらない)で評価す る尺度である。ネットワークの形成はパートナーシップの基盤と考えられている(Chrisman et al., 2002)。したが って、NEP 尺度と PDPA 尺度の間に強い相関関係を期待した。

\section{【分析方法】}

最初の項目の開発過程において、項目の内容的妥当性の調査を行った。全国調查では、項目分析、妥当 性及び信頼性の検討を行った。統計処理には windows 版 SPSS20.を用いた。

項目分析は、平均值及び標準偏差による天井効果・床効果の検討、及び P-P プロットによる正規性の検 討、Item-Total correlation Analysis (I-T 分析)、各項目間の相関の検討、Good-Poor analysis (G-P 分析) を行った。項目間相関で、0.7 以上の組み合わせの項目については、項目の意味内容を吟味し、他の項目 に同様の意味内容が含まれているかを検討した。

妥当性は、構成概念妥当性の検討にむけた因子分析、基準関連妥当性の検討に向けた外部変数との相 関係数の分析を行った。因子分析は、主因子法による探索的因子分析を行った。因子の固有值が 1 以上、 項目の因子負荷量が 0.4 以上を示し、かつ複数の因子に 0.4 以上の因子負荷量を示さないことを条件として、 
因子および項目を採用し、抽出した因子について項目内容に基づき因子を命名した。

信頼性は、尺度の折半法、各項目を除外した場合の Cronbach’s $\alpha$ 係数、各因子の Cronbach’s $\alpha$ 係数を 算出し検討した。

\section{結果}

PDPA 尺度の項目の生成のためにインタビューを行った保健師は 10 名で、全員が女性だった。保健師の 年齢は, 44.9 才(標準偏差 $[\mathrm{SD}]: 10.5$, 範囲 30〜60 歳)、県の範囲は 5 県であり、市区町村の人口規模は 18,000〜670,000 人であった。平均面接時間は、77 分(57〜92 分)だった。

インタビューデータを質的に分析した結果、保健師の地域組織との活動とその活動前後の取り組みにつ いて、266 文脈を抽出した。これらの文脈を、質的帰納的に分析した結果、27 項目で構成された。最後に、 文献検討と研究者間の協議を経て、30 項目の活動を抽出した。質的データは、5つの領域から構成された。 それは、健康課題に関連寸る情報の地域組織との相互理解に向けた取り組み、地域の健康課題の改善に 向けた地域組織との役割共有、パートナーシップの評価、地域組織との保健活動の推進に向けた基盤整備、 自治体の保健関係部署の一貫した関わりの調整だった。

次に、専門家の調査により、項目の妥当性を評価した。I-CVI は、各項目は 0.82〜1.0であり、削除する項 目はなかった。S-CVI/Ave は、0.93 であり、30 項目のPDCAスケールは、項目の妥当性を保証するものであ つた。

表 1 に、郵送法による調査の回答者の属性を示した。保健師に対する質問紙調査の回答者は、女性 98.1\% 男性 1.9\%だった。回答者の年齢は、全国の保健師の年齢と比較すると 40 歳代と 50 歳代で多く、経 験が豊富な回答者だった。市町村規模は、全国と同様の傾向があった。表2は、30 項目の項目分析の結果 を示した。評価尺度原案の各項目に関する平均值は 1.00〜2.28、標準偏差は 0.74〜 1.04 だった。項目 19 は、天井効果を示した為、尺度項目から除外した。その他の項目は、天井効果、床効果は認められなかった。 また、P-P プロットから全項目において正規性を認めた。 
項目 19 を除いた項目について、I-T 分析、項目間相関の分析、G-P 分析を行った。各項目の I-T 相関係 数は $0.55 〜 0.76$ の範囲だった。項目間相関係数を算出した結果、2と3、7と8、14 と $15 、 27$ と $29 、 29$ と 30 の5組で、相関係数 0.7 以上の相関を認めた。これらの項目の意味内容を吟味し、他の項目に同様の意味 内容が含まれていると判断した項目 $2 、 14 、 29$ を削除した。

$\mathrm{G}-\mathrm{T}$ 分析は、合計得点の中央值 (48 点) で、得点の高い上位群 (442 人、48 点以上) と得点の低い下位群 （459人、48 点未満）に分けた。各項目の得点の群間差についてt検定を行った結果、全項目で有意差 ( $\mathrm{p}<0.01)$ を認めた。

以上より、26 項目をその後の分析対象とした。構成概念妥当性を検討するため、26 項目の因子分析を行 つた。探索的因子分析の、主因子法による結果は、固有值1以上で4因子だった。その後、探索的因子分析 にて、主因子法、プロマックス回転で4つの因子を抽出した。1、20、21 の項目が複数の因子に高い因子負

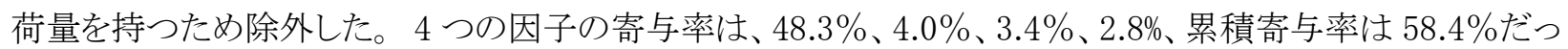
た。23 項目の尺度の平均は 36.3 標準偏差 14.9 だった。

各因子項目の内容を吟味し、第一因子を「健康課題に対する役割共有にむけた取り組み」、第二因子を 「パートナーシップ推進に向けた基盤整備」、第三因子を「パートナーシップの評価」、第四因子を「健康課題 に関する情報の発信」と命名した。

因子分析で得られた4因子 23 項目について信頼性の検討を行った。折半法の信頼係数は 0.91 、評価尺 度全体のクロンバック $\alpha$ 係数は 0.95 であった。因子毎の $\alpha$ 係数は因子 1 が 0.92 、因子 2 が 0.84 、因子 3 が 0.88、因子 4 が 0.82、であり、高い内的整合性が認められた。各項目の除外前の因子と各項目を除外した場 合、および各項目の除外前の評価尺度全体と各項目を除外した場合のクロンバック $\alpha$ 係数を比較した結果、 いずれの項目も除外前の因子や評価尺度全体の $\alpha$ 係数を超えなかった。また、各項目を除外した場合のク ロンバック $\alpha$ 係数は 0.95 以上であり、内的一貫性を脅かす項目はなかった。

PDPA 尺度と外的基準の NEP 尺度との相関分析の結果を表4に示す。NEP 尺度は、平均 53.3、標準偏差 14.2 だった。PDPA 尺度と NEP 尺度の尺度全体同士の相関は、( $\mathrm{r}=0.54, \mathrm{P}<0.01)$ であり中等度の相関があ ১た。 


\section{考察}

本研究により、4 因子 23 項目で構成された PDPA 尺度を開発した。PDPA 尺度は、信頼性を折半法に よる信頼係数、内的一貫性係数により確認した。そして、妥当性を、項目の内容的妥当性、因子分析、 基準関連妥当性の検討により確認した。これらの結果は、PDPA 尺度が、保健師と地域組織のパート ナーシップ構築活動を評価する信頼性と妥当性のある尺度であることを示した。

パートナーシップ構築について評価できる既存の尺度として、オーストラリアで開発された、戦略 的なトップダウンのパートナーシップ構築活動を評価する尺度(VicHealth，2011)が存在する。しか し、日本のパートナーシップの構築の活動は、日常の地域組織との関係をパートナーシップの関係に 築いていくボトムアップ活動である。その為、本研究で、日本の特徵を踏まえたパートナーシップ構 築活動を評価できる尺度を開発した。

新しく開発した尺度の項目は、健康問題と各組織の活動に関する情報の共有、役割と責任の分担、 協働する活動、評価等、西欧の戦略的な活動(Keller, Strohschein, Schaffer, and Lia-Hoagberg, 2004)と同じ項目だけでなく、既存の尺度とは違う日本におけるパートナーシップ構築にむけた特徵 的な活動に関する項目を含んでいた。

第一因子【健康課題に対する役割共有にむけた取り組み】は、日常の活動を通じて、地域の健康問 題や各組織の強みと弱みを含んだ活動を役割共有しながら、ネットワーク形成などの活動の質向上へ の取り組みや活動機会の拡大等の役割共有に向けた活動を行う特徵があった。戦略的なプロセスでは、 根拠に基づいた政策・計画の決定からパートナーシップ構築に向けた活動が始まり(Buckett, Williams, and Wildgoose, 2011)、人材と資金調達を必要とする(Dowling et al., 2004)。しかし、日 本では、保健師は、地域組織との関係をつくり地域社会に欠けている資源を豊かにする活動を行い (Yoshioka-Maeda et al., 2006)、地域組織のエンパワーをしつつ、協力し合える関係を深める働きか けをしている。また、戦略的パートナーシップと同様に、個人、家族、または地域社会の理解や対話 
の促進、役割変更への取り組み(Courtney et al., 1996)、協力関係の確立・維持(Buckett et al., 2011) にむけた活動をしている。

第二因子【パートナーシップ推進に向けた基盤整備】では、パートナーシップにむけた行政全体の統 合したアプローチ(Perkins, Smith, Hunter, Bambra, and Joyce, 2010)にむけて、行政と地域組織と の橋渡し役としての活動をしている。保健師は、日本の保健医療制度における地方自治体の中で公衆 衛生にかかわる基盤整備に関する責任や説明責任、そして行政内の各部署と地域組織との橋渡しの役 割を担っている。これらの活動は、しっかりと受け入れられ、継続的に行われる必要がある。日本の 保健師は、このような重要な役割を担っている。

第三因子は、【パートナーシップの評価】である。The Institute of Medicine (2002) は、政府の あらゆるレベルでの公衆衛生機関のコア機能の一つとして評価をあげている。また、保健師は、評価 における役割と責任を持つことが報告されている(American Public Health Association, 1996)。第 三因子には、パートナーシップの評価にむけた、活動を通して効果のモニタリングを行い、進捗状況 や成果を評価し、レポートして公表し、次年度の計画に活か寸活動が含まれている。評価を保健師だ けでなく地域組織と行うことは、パートナーシップの過程において、重要であるといわれている (Navruzov, Rose, and Shelley, 2000)。活動の透明性も重要である。尺度はパートナーシップ構築活動の どの段階においても評価の必要性を示した。活動を行いながら評価を行うことで、Plan-Do-Check —Action のサイクル(Baker, Mackintosh-Murray, Porcellato, Dinne, Stelmacovich, and Born, 2008)がより実態にあわせて展開でき、パートナーシップの推進が期待できる。

第四因子【健康課題に関する情報の発信】は、地域課題に関する情報及び行政の活動の限界を地域 組織が理解しやすいように公開することである。ある研究では、住民へ透明性の高い情報を提供する ことは保健部門の責任であると述べている (El Ansari, Phillips, and Zwi, 2004)。今回の結果では、行政 の限界に関する情報発信について示された。パートナーシップの役割や責任の共有をするにあたつて、 強みだけでなく弱みを含めた両側面に関する情報交換の必要性を示している。

PDPA 尺度は、継続的な、情報交換の実施、開かれた討論、自治体内の様々な組織が公衆衛生の向 
上にむけた取り組むための活動について、評価する項目を含んでいる。これらの項目は、パートナー シップの発展に向けた重要な要素である。今後、健康格差の少ない地域社会を目指して、地域組織の 目的、構造そして活動の多様性を考慮し、地域組織とのパートナーシップ構築活動を細かく分析し、 本尺度を汎用性のある尺度とするために開発を進めていく必要がある。

本研究は、いくつかの限界がある。全国市町村の保健師に対する質問紙調査の募集において、配布 先を考慮することによって返答が増加する可能性がある。本研究では、保健師管理者を通して、地域 組織とパートナーシップを構築している保健師を間接的に募集した。しかし、回答者は 901 人であ り、所属自治体の人口の全国との比較において偏りが少なかった。また、全ての自治体への全国調査 であったため、日本全体の傾向を示すことができるサンプルが収集できたと考える。もう一つの限界 は、外的基準がネットワーク形成実践技術尺度のみであったことである。パートナーシップの構築の 成果に関する尺度を用い妥当性を検討することは、本尺度を改良するために必要である。更なるデー タ蓄積や尺度の精度の検証が今後の課題である。

本尺度は、このような限界はあるが、実践家へのインタビューによる尺度項目の生成、文献検討と 専門家への調査による内容的妥当性の検討そして全国調査による信頼性・妥当性の検討という、体系 的な過程を経て開発された尺度であり、パートナーシップ構築を行っている保健師にとって有効な信 頼できる尺度である。本尺度は、保健管理者が、地域組織とのパートナーシップを構築するために、 パートナーシップ構築の出発点として、地域組織とのパートナーシップ構築活動を改善したいとき等 の各段階の活動の評価に用いることができる有効な尺度である。また、地域組織とのパートナーシッ プ構築活動の概念を示し、その活動の測定が可能であるため、地域組織とのパートナーシップ構築に 関わる保健管理者向けの手引きやプロセスの監視や改善にむけた評価に使用することができる尺度 である。

\section{謝辞}

本研究は、科学研究費補助金基盤研究（23593377）の助成を受けた。調査にあたりお忙しい中ご協 力いただいた保健師と研究者の皆様に感謝申し上げます。 
表1 回答者の概要と日本のデータの比較

\begin{tabular}{crr}
\hline & 回答者の概要 $(n=901)$ & $\mathrm{N}(\%)$ \\
\hline 性別 & & 日本のデータ*,** \\
女性 & $884(98.1)$ & $46,549(98.5)$ \\
男性 & $17(1.9)$ & $730(1.5)$ \\
年齢(歳) & & \\
$\leq 29$ & $83(9.2)$ & $7,553(16.0)$ \\
$30-39$ & $241(26.7)$ & $14,584(30.8)$ \\
$40-49$ & $317(35.2)$ & $13,539(28.6)$ \\
$50-59$ & $257(28.5)$ & $9,365(19.8)$ \\
$60 \leq$ & $3(0.3)$ & $2,238(4.7)$ \\
所属自治体規模 & & \\
\multicolumn{1}{l}{$\leq 10,000$} & $172(19.1)$ & $482(27.5)$ \\
$10,000-30,000$ & $194(21.5)$ & $462(26.4)$ \\
$30,000-50,000$ & $135(15.0)$ & $245(14.0)$ \\
$50,000-100,000$ & $191(21.2)$ & $272(15.5)$ \\
$100,000-300,000$ & $146(16.2)$ & $205(11.7)$ \\
$300,000-1,000,000$ & $55(6.1)$ & $73(4.2)$ \\
$1,000,000 \leq$ & $8(0.9)$ & $12(0.7)$ \\
\hline
\end{tabular}

*日本の保健師の概要 (2012) (Sex, Age); 厚生労働省).

**日本の自治体の規模(2010); 総務省統計局. 


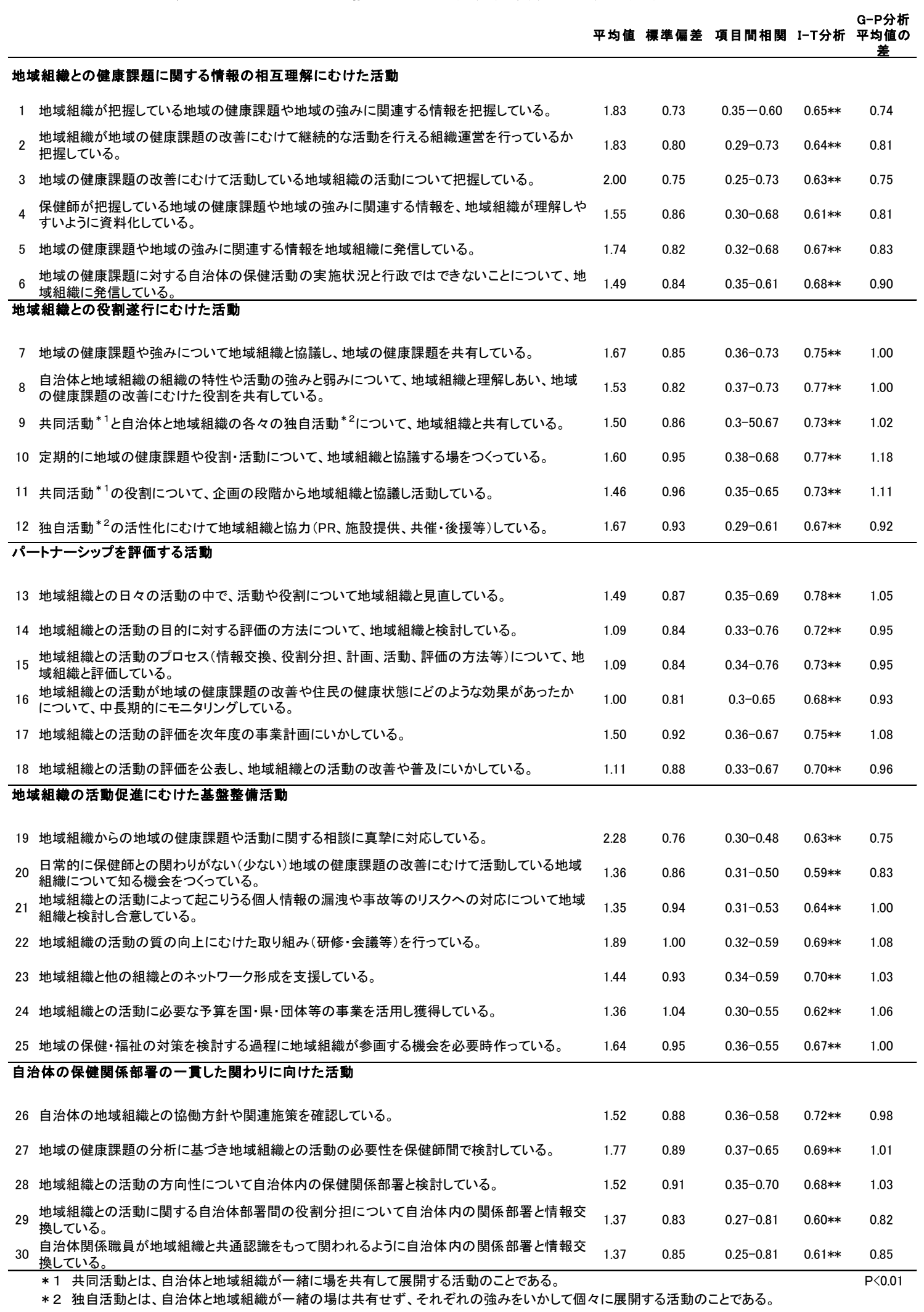


表3 パートナーシップ構築プロセス評価尺度23項目の因子分析結果 (4因子23項目、全体の $\alpha$ 係数 $=0.95)$

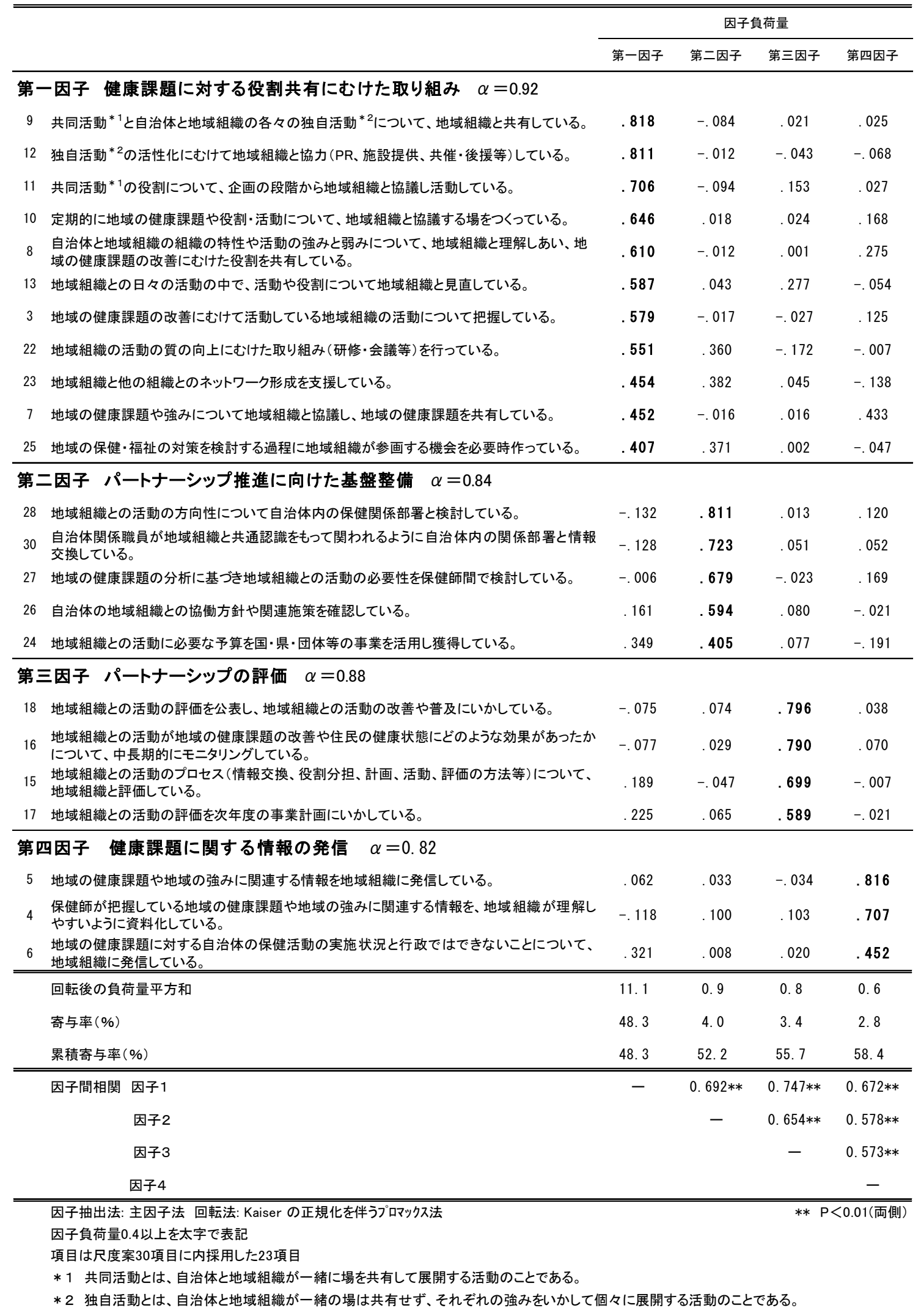


表4 パートナーシップ構築プロセス評価尺度とネットワーク形成実践技術尺度との相関

\begin{tabular}{|c|c|c|c|c|c|}
\hline \multirow{3}{*}{ 外部変数 } & \multicolumn{5}{|c|}{ Pearson の相関係数 } \\
\hline & \multirow{2}{*}{ 尺度全体 } & 第一因子 & 第二因子 & 第三因子 & 第四因子 \\
\hline & & $\begin{array}{c}\text { 健康課題に対する役割共有 } \\
\text { にむけた取り組み }\end{array}$ & $\begin{array}{c}\text { パートナーシップ推進に向 } \\
\text { けた基盤整備 }\end{array}$ & パートナーシップの評価 & 健康課題に関する情報の発信 \\
\hline $\begin{array}{c}\text { ネットワーク形成実践技術尺度 } \\
{[\mathrm{Av}=53.3 \mathrm{SDD}=14.2]}\end{array}$ & $.525^{* *}$ & $460^{* *}$ & $.500^{*+*}$ & $.413^{* *}$ & $.475^{* *}$ \\
\hline
\end{tabular}

